\title{
THE USE OF DIGITAL IMAGE PROCESSING IN ANALYSIS OF BORON, CADMIUM IN THORIUM OXIDE WITHOUT CARRIER DISTILATION WITH EMISSION SPECTROGRAPH METHOD
}

\author{
Sahat Simbolon, Aryadi, Muhtadan* \\ Centre for Accelerator and Material Process Technology (CAMPT) \\ *Polytechnique Institute of Nuclear Technology, Yogyakarta \\ National Nuclear Energy Agency, Yogyakarta \\ simbolon@batan.go.id
}

Recived on 13 September 2011, the revised script on 3 February 2012, accepted on 10 February 2012

\begin{abstract}
THE USE OF DIGITAL IMAGE PROCESSING IN ANALYSIS OF BORON, CADMIUM IN THORIUM OXIDE WITHOUT CARRIER DISTILLATION EMISSION SPECTROGRAPH METHOD. The use of digital image processing in direct determination elements of highly absorption cross-section of thermal neutron such as $B$ and $\mathrm{Cd}$ in nuclear fuel $\mathrm{ThO}_{2}$ without carrier distillation was described. Working and counter electrode should be modified because volume of the sample was larger than the traditional one. Firstly, analysis of $\mathrm{B}$ and $\mathrm{Cd}$ in $\mathrm{ThO}_{2}$ was recorded by $X$-ray film for thorax and then was proceeded by mini digital camera. All files in mini digital camera were transferred to computer and read by digital image processing of Matlab software. It was found that all line spectra became Gaussian shape. Since couple of camera position and lightening system had not been done successfully yet, therefore, quantitative analysis could not been done yet, meanwhile qualitative analysis had already been done by analysis spectra after image processing. It is easier to analysis $B$ and $C d$ qualitatively use of image processing than densitometer instrument.
\end{abstract}

Keywords : Thorium Oxide, Carrier Distillation, Image Processing, Digital Camera

\section{ABSTRAK}

PENGGUNAAN PROCES CITRA DALAM ANALISIS BORON DAN KADMIUM DI DALAM TORIUM OKSIDA TANPA DISTILASI PENGEMBAN DENGAN METODA SPEKTROGRAF EMISI. Digambarkan penggunaan proses citra dalam penentuan secara langsung unsur-unsur yang mempunyai tampang lintang absorbsi neutron yang besar seperti $B$ dan $C d$ di dalam torium oksida tanpa distilasi pengemban. Elektroda kerja dan elektroda counter dimodifikasi karena volume cuplikannya lebih besar daripada volume cuplikan yang biasa digunakan. Awalnya, analisis $B$ dan $C d$ di dalam torium oksida tanpa distilasi pengemban direkam dengan film sinar-X untuk toraks kemudian difoto dengan kamera digital mini. Semua data di dalam kamera digital mini kemudian ditransfer ke komputer dan dibaca dengan perangkat lunak Matlab, spektra garis berubah menjadi spektra berbentuk Gaussian. Oleh karena kopel posisi kamera dengan sistem pencahayaan belum berhasil direkayasa, sehingga analisis kuantitatif belum dapat dilakukan, sementara itu analisis kualitatif sudah berhasil dilakukan. Lebih mudah menganalisis unsur $B$ dan $C d$ secara kualitatif setelah melalui proses pencitraan daripada menggunakan instrumen densitometer.

Kata Kunci : Torium Oksida, Pengemban Distilasi, Proses Citra, Kamera Digital

\section{INTRODUCTION}

Nowadays fossil material such oil, coal, and gases are still dominant to be energy resources for transportation, electricity etc. One day all fossil material energy resources above will decrease, on the other hand, the world still needs energy. Electricity power which uses coal as a fuel will give off ashes and greenhouse 
gas $\mathrm{CO}_{2}$ which brings about global warming ${ }^{(1)}$. Many nuclear power for electricity have been constructed in many countries in order to have a sustainable power. Uranium, usually, is used for nuclear fuel in nuclear reactor because uranium nuclei is fissionable, on the other hand, thorium is not a fissionable material when react with thermal neutron, thorium is a fertile material, so thorium could not be used directly in nuclear reactor to produce electricity. Thorium-232 should be first converted into U-233 in a nuclear reactor and U-233 is fission material that can be used as a nuclear fuel. From abundance point of view in mine, thorium is more abundant than uranium. ${ }^{(2,3)}$ So, thorium could be used as a future nuclear fuel. Thorium as a basic material for U-233 should be free from impurities elements especially from large cross-section of thermal neutron such as boron (767 barns), cadmium (2450 barns) and some rare earth elements such gadolinium (49,000 barns), samarium (5922 barns). ${ }^{(4)}$

Some analytical methods either direct or indirect methods have been applied for the determination of impurities elements in nuclear fuel compound. Indirect analysis method, such as ICP-AES (Inductively Coupled Plasma - Atomic Emission Spectroscopy) analysis based on a high temperature argon plasma which is supplied by radiofrequency equipment. It brings about boron and cadmium in the solution form could emit their specific spectra $^{(5)}$. $\mathrm{ThO}_{2}$ matrix is extracted prior to the determination impurities elements by ICP-AES method. For quantitative analysis purposes, a series of standards and samples are carried out on the same condition. A major advantage of this method is that high precision, longer calibration curve, low detection limit and the experiment is not tedious to do. However, the price of ICP-AES instrument is very expensive, this is one of a major disadvantage of this method.

Conventional direct analysis method, such as emission spectrograph analysis based on DC arc on graphite electrode and the mixture of carrier distillation of $\mathrm{Ga}_{2} \mathrm{O}_{3}$, LiF and $\mathrm{Ag}_{2} \mathrm{O}$ has been usually used ${ }^{(6)}$. The mixture of carrier distillation of $\mathrm{Ga}_{2} \mathrm{O}_{3}$, $\mathrm{LiF}$ and $\mathrm{AgCl}$ mixture were added to $\mathrm{ThO}_{2}$ powder. Powder of $\mathrm{ThO}_{2}$ in this experiment was produced through calcination of $\mathrm{Th}\left(\mathrm{C}_{2} \mathrm{O}_{4}\right)_{2}$ in a furnace at $600^{\circ} \mathrm{C}$ for 2 hours. As a consequence, this method produces rather high detection limit, low precision and linearity of calibration curve is limited. In addition, the application of spectrograph emission to the analysis appeared to be stymied by instrumental limitation including tedious preparation, heavy matrix effect and difficulties of reading lines spectra recorded on X-Ray film for thorax. Emission spectrograph work reported in this study was performed with Matlab software, spectral Gaussian is obtained instead of spectral lines. It is an important tool for qualitative analysis as depicted in Figure 1.

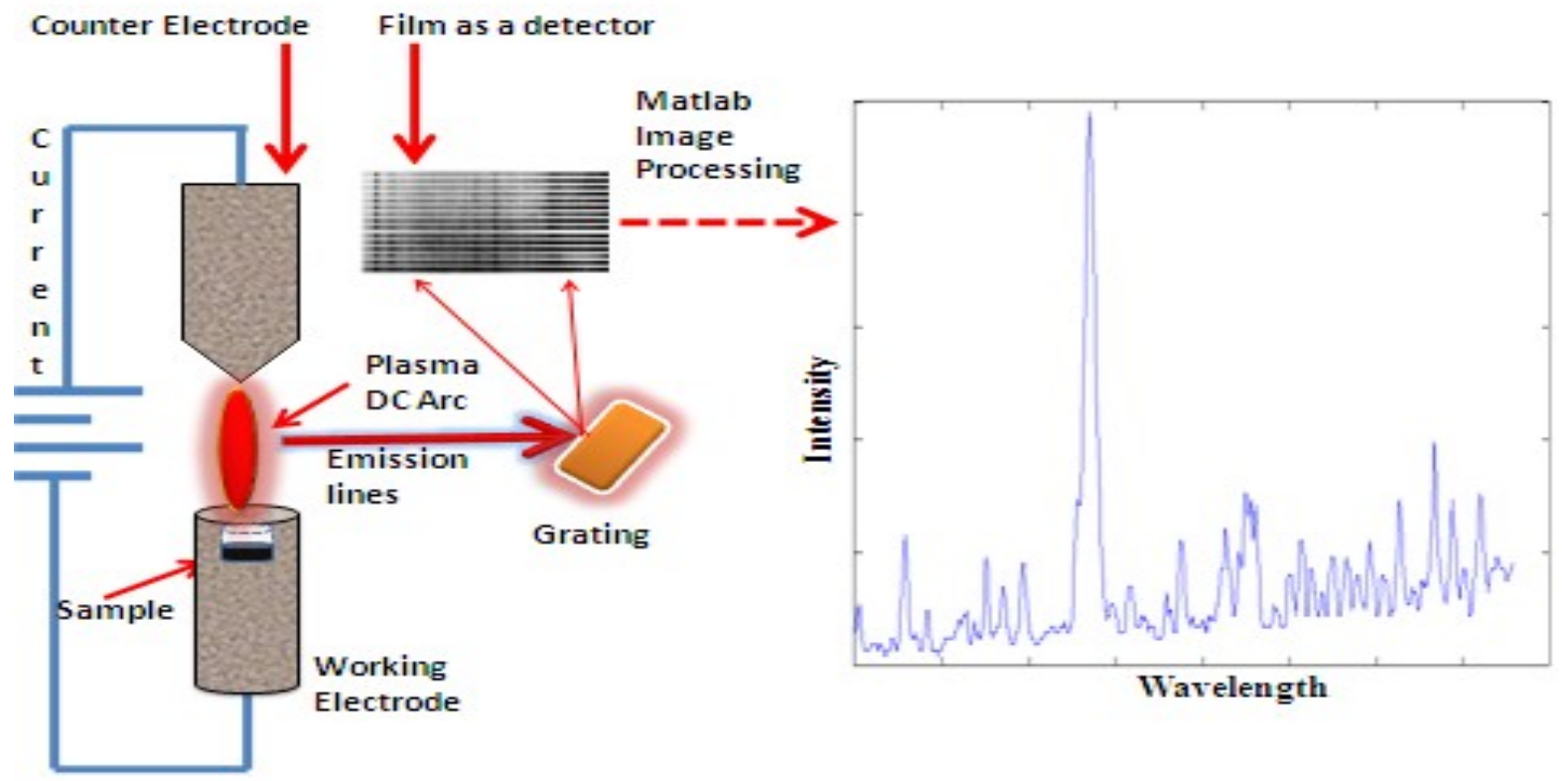

Figure.1. Image Processing of Spectra and Overview Diagram of Spectrograph Emission System 
Despites its limitations, spectrograph emission does have major advantage because it is attractive in analysis in solid form and it also eliminates many steps of pretreatment samples or standards prior to analyze. Moreover, lot of information could be recorded in X-Ray film for thorax as a detector. However, reading lines spectra conventionally with densitometer instrument is not easy to do. Moreover, in the near future, from carrier distillation scarcity or supply point of view, will not be easy to find in market. Therefore, an alternative approach is developed to assess. ${ }^{(6)}$

Since homemade electrode has been used succesfully to analysed impurities elements in nuclear fuel ${ }^{(6)}$ and the use of image processing in qualitative analysis was done. The goal of this experiment is development of analysis of nonmetallic boron and metallic cadmium in thorium oxide which was conducted without carrier distillation and digital imaging processing was used to analyze lines spectra qualitatively. In these experiments, counter and working electrodes have to be modified by enlarging in order to be fitted to the sample volume.

\section{EXPERIMENTAL}

\section{Material}

1. Thorium nitrate (CAMPT), $\mathrm{HNO}_{3}$ (Merck), TBP(Merck), kerosene (Fisher)

2. Film for thorax, Developver D19B and Kodak Rapid Fixer

3. Specific size graphite rod electrode (CAMPT)

4. Standard powder of cadmium oxide $(0.011423 \mathrm{~g})$ (Spex Industries)

5. Standard powder of boric acid $\left(\mathrm{H}_{3} \mathrm{BO}_{3}\right) 0.005719 \mathrm{~g}$ ) (Spex Industries)

\section{Equipment}

The equipment used in the experiment consisted of glassware, beaker glasses, Erlenmeyer flasks, extraction separator, vial polyethylene for standards and samples, balance Sartorius 2405; pH Meter (Mettler), oven; lathe-Horison M-300; Emission Spectrograph 3.4 m Ebert type (Jarell Ash). Spectrograph 3.4 m Ebert type Jarell Ash

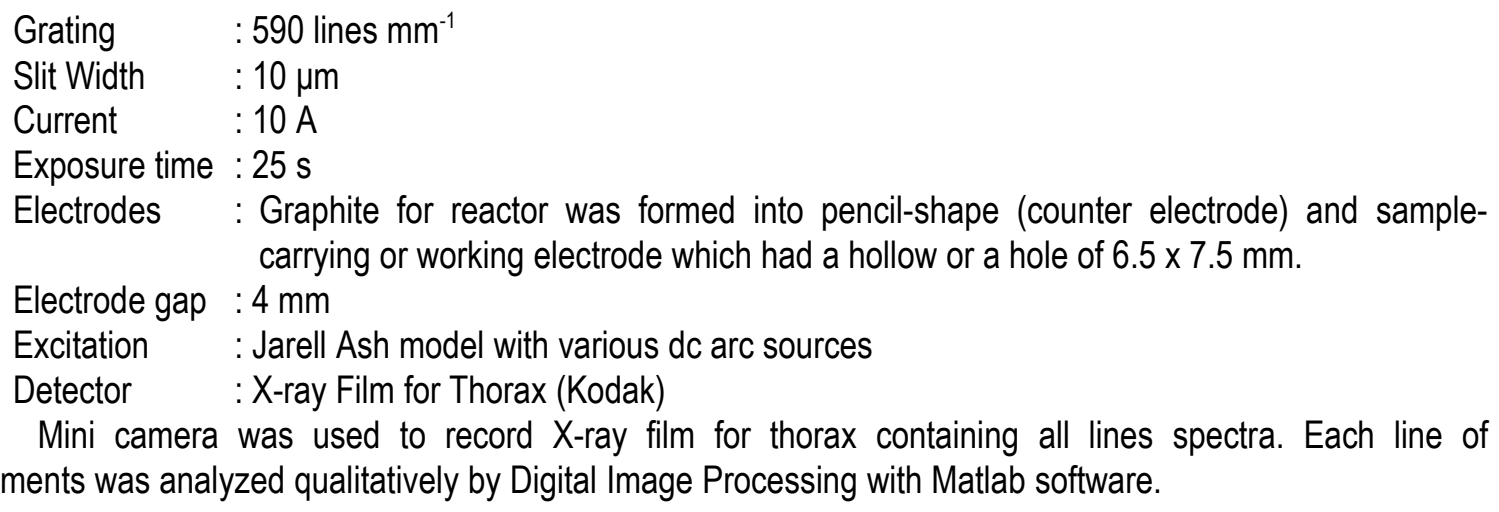

\section{Procedure}

\section{Preparation of standards}

Aqueous solution and solid form of thorium nitrate were collected, dissolved in $\mathrm{HNO}_{3}$ and heated to dryness alternately dissolved with $\mathrm{HNO}_{3}$. Thousand $\mathrm{mL}$ thorium nitrate solution was heated on a hot plate at $100^{\circ} \mathrm{C}-120^{\circ} \mathrm{C}$ until volume of solution about $100 \mathrm{~mL}$. This was followed by extraction TBP-kerosen. Hundred $\mathrm{mL}$ thorium nitrate solution above was added into a $100 \mathrm{~mL}$ organic solution of mixture of TBP and kerosene (TBP $30 \%$ - kerosene 70\%). The mixture was shacked for 25 minutes and stirred for 10 minutes and the organic solution was separated from the aqueous solution. These steps were performed 4 times. All organic solutions were collected in a beaker glass, and the $250 \mathrm{~mL}$ of $3 \mathrm{M} \mathrm{HNO}_{3}$ was added and mixed for 1 hour, and eventually the organic phase and aqueous phase separated. Stripping process was performed by adding $250 \mathrm{~mL}$ of demeneralized water and heated on hot plate at a temperature of $60^{\circ} \mathrm{C}-70^{\circ} \mathrm{C}$ for about 1 hour. The organic phase was separated from aqueous phase in a funnel separator. The thorium nitrate solution was then dried 
using a hot plate, and the thorium nitrate cristal obtained was calcinated in a furnance at $850^{\circ} \mathrm{C}$ for 3 hours. Eventually, it was found pure thorium oxide. Figure 2 illustrated the process steps of thorium oxide pure.

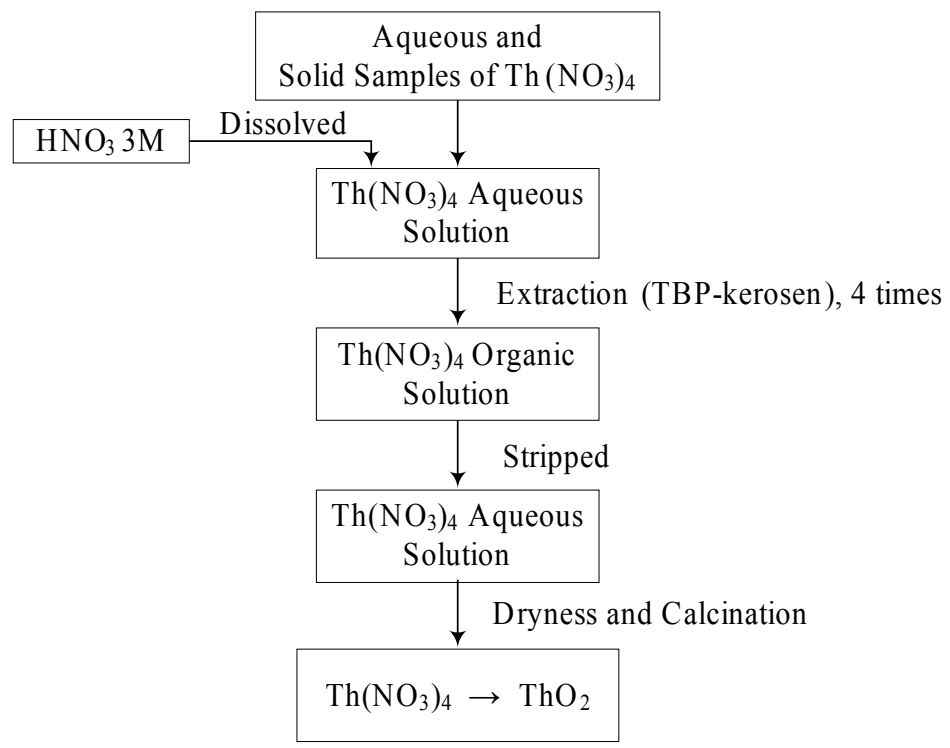

Figure 2. Block Diagram of $\mathrm{ThO}_{2}$ Preparation

\section{Preparation of synthetic standard boron and cadmium in $\mathrm{ThO}_{2}$ matrix.}

Eleven point five $\mathrm{mg}$ of $\mathrm{CdO}$ and $988.5 \mathrm{mg}$ of $\mathrm{ThO}_{2}$ were weighed, and then mixed and homogenized in a mortar for 1 hour. The same procedure was repeated for $57.194 \mathrm{mg} \mathrm{of} \mathrm{H}_{3} \mathrm{BO}_{3}$ and $942.806 \mathrm{~g}$ of $\mathrm{ThO}_{2}$. It was found that the amount of each standard cadmium and boron was $10000 \mathrm{ppm}$ in $\mathrm{ThO}_{2}$ matrix, $50 \mathrm{mg}$ of each standard boron and cadmium was weighed and mixed with $450 \mathrm{mg}$ of $\mathrm{ThO}_{2}$ matrix, and $1000 \mathrm{ppm}$ was obtained. Fifty mg of each standard (1000 ppm) was weighed and mixed with $400 \mathrm{mg}$ with $400 \mathrm{mg} \mathrm{ThO}_{2}$, and $100 \mathrm{ppm}$ of each boron and cadmium was found in the $\mathrm{ThO}_{2}$ matrix. The above powder mixture was subsequently diluted with $\mathrm{ThO}_{2}$ and homogenized to obtain a series of standards which contain $0.3 \mathrm{ppm} ; 0.5 \mathrm{ppm} ; 0.7 \mathrm{ppm} ; 1 \mathrm{ppm} ; 3$ $\mathrm{ppm} ; 7 \mathrm{~mm}$ and $10 \mathrm{ppm}$ of boron and cadmium in the $\mathrm{ThO}_{2}$ matrix. Samples were prepared in an identical with standards.

\section{Preparation of Electrodes}

A block of graphite for moderator nuclear reactor was formed to be many graphite rod electrodes. Two kinds electrodes, they were, pencil-shape (counter electrode) and sample-carrying or working electrode which had a hollow or hole of $6.5 \times 7.5 \mathrm{~mm}$ were made. Five hundred $\mathrm{mg}$ of each standards and samples were deposited on working electrode hole. The counter and working electrode were put in enclosed box which has room condition.

\section{RESULTS AND DISCUSSION}

\section{Preparation Synthetic Reference Material}

Standards of thorium nitrate and thorium oxide were a home made or Synthetic Reference Material (SyRM), therefore liquid-liquid extraction should be done carefully controlling extraction parameters. One of the important organophosphorus solvents for nuclear elements is tributylphosphate (TBP), it forms a stable complex with thorium cation, and TBP does not react with cation which has oxidation state $3^{+}$and $2^{+}$. $(6,7)$ Reaction of $\mathrm{Th}\left(\mathrm{NO}_{3}\right)_{4}$ in aqueous solution and TBP in kerosene (organic phase) occurs on the interface between organic and aqueous phase. The solvent extraction of the $\mathrm{Th}\left(\mathrm{NO}_{3}\right)_{4}$ with TBP is believed to proceed through coordination reaction between $\mathrm{Th}\left(\mathrm{NO}_{3}\right)_{4}$ and TBP. Complex molecule $\mathrm{Th}\left(\mathrm{NO}_{3}\right)_{4}$.TBP moves through interface between aqueous and organic phase. Liquid-liquid extraction, actually, is a complex reaction, but overall reactions can be written as follows, 
The use of digital image processing in analysis of Boron, Cadmium in Thorium Oxide without carrier distillation emission spectrograph method (Sahat Simbolon., et al)

$$
4\left[\mathrm{TBP} . \mathrm{H}_{2} \mathrm{O}\right]_{(\text {org })}+\mathrm{Th}\left(\mathrm{NO}_{3}\right)_{4(\mathrm{Aq})} \rightarrow\left[\mathrm{Th}\left(\mathrm{NO}_{3}\right)_{4} .4 \mathrm{TBP}\right]_{(\text {org })}+4 \mathrm{H}_{2} \mathrm{O}_{(\mathrm{Aq})}{ }^{(8)}
$$

Impurities elements in aqueous phase react with TBP-kerosen in a very small amount or can be ignored, meanwhile thorium nitrate form is transferred to organic phase, so aqueous phase contains impurities elements. TBP-kerosen is the best organic substance for thorium nitrate, but no chemical substance fully selective for thorium nitatre ${ }^{(7,8)}$. Therefore, thorium nitrate in aqueous phase was extracted four times in order to be all thorium nitrate in aqueous move to organic phase completely and practically, impurities elements are still in aqueous phase. Thorium nitrate in organic phase was assumed to be free of impurities elements since impurities elements do not react with TBP. After stripping process, all thorium nitrate was back to aqueous phase which was free of impurities elements. ${ }^{(6,8)}$

\section{Excitation and Stable Matrix}

Thorium nitrate is not stable in high temperature, it will be decomposed into thorium oxide and $\mathrm{NO}_{2}$ therefore, calcinations of thorium nitrate should be done prior to atomization ${ }^{(9)}$. If thorium nitrate were used as a matrix which is not chemically stable it would produce strong interference from chemical and physical reaction during the excitation. Since excitation process is done in high temperature and in very short time, and complexity physical and chemical reaction in working electrode and the possibility of residence time for complete excitation either for sample or standard is not same. Therefore, the possibility of impurities B and Cd from samples and standards loss is increased ${ }^{(6)}$. So, it is hard to perform for impurities elements analysis in unstable matrix use of high temperature and in very short time method of analysis. To allow sufficient sample and standard residence time in plasma, matrix of the sample and graphite electrode should be stable in high temperature and in very short time ${ }^{(6)}$

Conventionally, analysis impurities elements in nuclear fuel by emission spectrograph use carrier distillation, which is mixture of $\mathrm{Ga}_{2} \mathrm{O}_{3}, \mathrm{AgCl}$ and $\mathrm{LiF}$, are mixed with samples and standards separately ${ }^{(6)}$. It is typically used as a volatility enhancer impurities elements only in conjuctions with stable matrix of $\mathrm{ThO}_{2}$. Carrier distillation in working electrode where samples or standards had been introduced will enhance volatility of $B$ and $\mathrm{Cd}$ when $\mathrm{dc}$ arc is ignited. This is one of the most important parameters influencing the analysis of impurities of $\mathrm{B}$ and $\mathrm{Cd}$ in thorium oxide. As the applied current continues, electrons accelerated across the counter and working electrode gap it brings about the temperature increases. Traditionally, it takes only 25 seconds to record all spectra emitted in a photographic detector of X-ray film for thorax, but 10 seconds were used for stability ${ }^{(9)}$. Temperature on the working electrode is rising dramatically from room temperature to around $1000^{\circ} \mathrm{C}$ in 25 seconds, after 25 seconds experiment was automatically stopped. Either excitation of samples or standards in working electrode or recording spectra emitted are ended. From stability of graphite electrode and thorium oxide point of view, rising temperature dramatically between counter and working electrode is one of critical point of this experiment. Produce atomization, excitation and deexcitation events of impurities elements $\mathrm{B}$ and $\mathrm{Cd}$ in $\mathrm{ThO}_{2}$ in working electrode actually are so complex. If matrix thorium oxide were not stable in rising temperature dramatically of dc arc plasma, so chemical and physical reaction of matrix would heavily influence excitation of $B$ and $\mathrm{Cd}$ impurities elements in thorium oxide. It is a compulsory for the system, in this case of thorium oxide matrix and graphite as a counter and working electrodes to reach a state of thermal in stability rising temperature dramatically is reached. If thorium oxide were stable, analyte signal of boron and cadmium either from samples or standards would also be lightly fluctuated ${ }^{(9)}$. Fluctuation of analyte $\mathrm{B}$ and $\mathrm{Cd}$ signal either from samples and standards would influence the quantitative analysis quality. To reduce fluctuated of complex reaction either in samples or in standards when the experiment is carried out, matrix thorium oxide should be stable in rising temperature dramatically. In addition, matrix matching or identical sample and standard which are introduced reproducibly into working electrode hole should be done, so B and $\mathrm{Cd}$ impurities elements in thorium oxide nominally undergo the same sequence of atomization or excitation. Therefore, boron and cadmium excitation in thorium oxide could be assumed free of matrix effects. It is generally agreed that, for quantitatively purposes, excitation of impurities elements such as boron and cadmium in thorium oxide is based on proportionate amount in standards and samples. In fact, small fluctuations show up in each experiment, it is unavoidable. Standard addition method is not recommended in this method because sample is in the powder form beside that each 
sample should be a new one including new electrodes. Since the precision and accuracy which are important in analytical criteria, reproducibility data found from this experiment is a necessary ${ }^{(10)}$. Long-term stability of DC arc ignition is important for emission spectrograph analysis method because measurements are carried out several times for analysis boron and cadmium in thorium oxide. If the working or counter electrodes were not stable in high temperature, samples or standards might be out of system during the excitation and it would be unsuccessful experiment ${ }^{(11)}$. Fortunately, thorium oxide compound and graphite either working or counter electrodes are a stable in high temperature of $\mathrm{dc}$ arc plasma ${ }^{(6)}$. Boron and cadmium excitations are also assumed as irreversible reactions, i.e. no excited boron and cadmium atoms which had emitted their characteristics lines are still in plasma dc arc. After emitting their lines, both of them are out of system, but thorium oxide as matrix is still in the system and produces background, this is a disadvantage of this method. For quantitative purposes, samples and standards are also assumed have no physical reaction brings about fluctuations and excitation process for sample and standard are uniform, so intensity of analyte is proportional to the amount of analyte B and Cd in sample and standard ${ }^{(6)}$.

Since the above experiments were carried out without carrier distillation, therefore, atomization and excitation of analyte of boron and cadmium process in samples or standards directly because of thermal in working electrode. Since sensitivity of boron and cadmium is expected to be directly proportional to the number of $B$ and $C d$ in thorium oxide excited in working electrode. So, the larger the amount of samples or the number of impurities elements in a sample or standard employed, the higher the sensitivity is ${ }^{(6)}$. So to compensate the useful of carrier distillation, the amount of sample and standard should be enlarged. As its consequences, the working and counter electrodes size should also be enlarged. In this experiment, the amount samples or standards of thorium oxide in working electrode have up to five times of traditional one, in consequence of bigger volume of samples or standards working electrode have up also five times of traditional one. Atomization mechanisms observed for larger which has no enhancer volatility in samples or standards might be differ from those seen for smaller which has enhancer volatility in samples or standards ${ }^{(10)}$.

\section{Detection and Digital Image Processing}

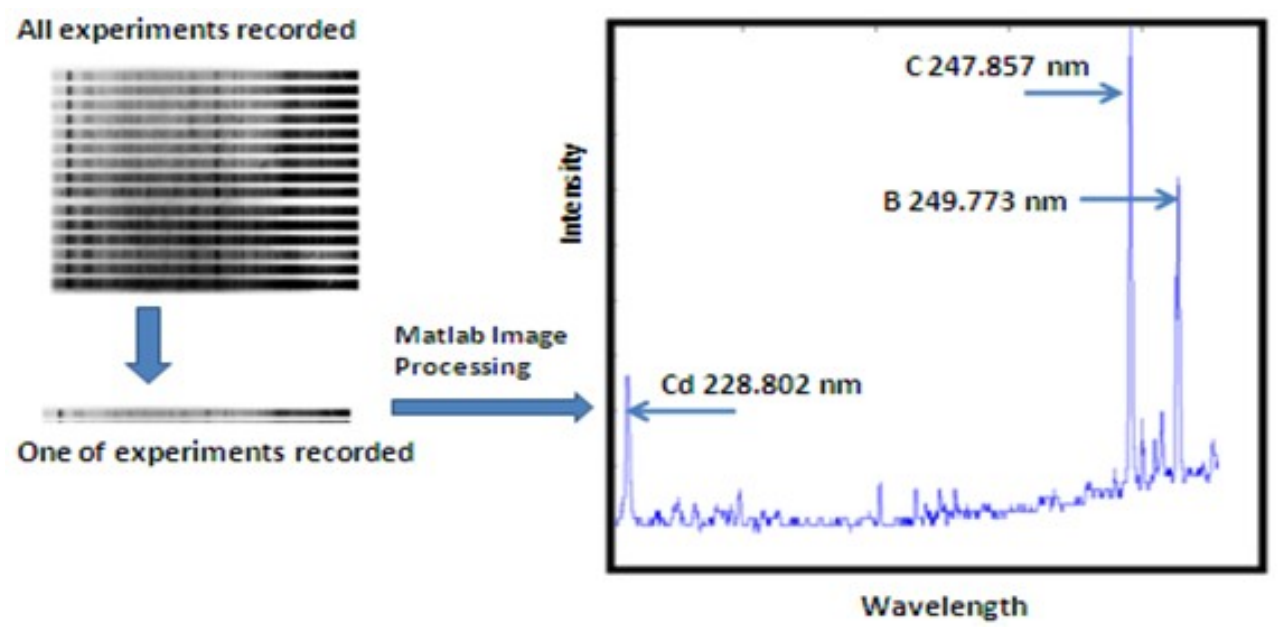

Figure 3. Converting analog recorded becomes spectral scan of one experiment

Established method of application densitometer is used to analyze spectra lines qualitatively and quantitatively based on characteristic line of analyte lines emitted, boron on $249.773 \mathrm{~nm}$ and cadmium on $228.802 \mathrm{~nm}$ respectively ${ }^{(6)}$. It takes much time to analyze each of them. There is a drawback associated with photographic detector of $X$-ray film for thorax, because there is lot of recorded spectra lines ${ }^{(6)}$. Analyzing spectral lines of $B$ and $C d$ from photographic detector of $X$-ray film for thorax is inconvenience due to crowded spectra lines in some region of interest. In addition, the distance between two closed lines of interest cannot be lengthened. Fortunately, recorded spectra lines or data in analog form on detector can be digitalized by use of digital imaging processing of MATLAB software. Raw data files in a photographic detector of X-ray film for thorax were converted first by simple digital camera. One of the experiments was selected and all data in jpg file form 
are read by image processing from MATLAB software. Region of interest, especially boron and cadmium spectra lines, can be selected as shown in Figure 3.

All spectra lines, analyte lines and interferences, are recorded on photographic detector of X-ray film for thorax as a detector and the data was recorded by mini digital camera. Then, data in camera was transferred into computer in jpg file. All the in jpg file can be read by digital imaging processing from Matlab software. In order to overcome crowded spectral lines, special region of interest can be chosen as shown in Figure 3 . Therefore, it is easier right now to analyze qualitatively spectra lines impurities elements such boron and cadmium as shown in Figure 3. Some difficulties are still encountered for quantitative purposes. The quantitative capability of new system, however, has not yet been fully examined because attempts to couple of lightning system and camera position have been unsuccessful done. Camera position and lightning system is very important factor, it brings about linearity, background and signal-noise relationship which are quantitative factor. If lightning system and camera position were done successfully, it would not be difficult to analyze boron and cadmium quantitatively in thorium oxide matrix using emission spectrograph method.

\section{Qualitative Analysis of boron and cadmium}

Emission spectrograph method for analysis impurities elements in thorium oxide provides multi elements analysis and undergoes complex physical and chemical reaction in working electrodes. Fluctuations and inter elements interference are not avoidable in these experiments. Detector used is a photographic detector of X-ray film for thorax which is capable of recording ultraviolet spectra including boron spectra $249.773 \mathrm{~nm}$ and cadmium spectra $228.802 \mathrm{~nm}$ respectively ${ }^{(6)}$. Others impurities elements, matrix thorium oxide and graphite electrode in high temperature emit lots of spectra lines, all lines are recorded permanently in detector used. Therefore, all information could be analyzed out of system, qualitatively and quantitatively. Since all ultraviolet are recorded, therefore, for qualitative analysis takes much time and needs lots of experiences. This is disadvantages associated with qualitative analysis use of densitometer. Ideally, recorded lines are limited just for analyte lines only, by arranging grating position. At least, not all lines are recorded on detector.

\section{Quantitative Analysis}

Traditionally, in almost any chemical analysis method is designed to be qualitative and quantitative analysis. Qualitative analysis has already done by computer help, meanwhile quantitative analysis method depends on comparison between analyte signal of a series of known concentration and unknown analyte signal. Therefore, a series of standards containing mixture of boron and cadmium in thorium oxide was used to set up for each calibration curve ${ }^{(6,10)}$. Simple seven-point calibration curve for boron and cadmium was performed by measuring analyte concentration for a variety of standard in optimum condition. Since the computer has been widely used, mathematically the first and the second order equation of calibration curve of $B$ and $C d$ were easy to be calculated from Table 1. In order to illustrate the relationship between intensities of $B$ and $C d$ and their concentrations, Matlab software was used to calculate first and second order calibration. Each point was measured three times (three replicates) and the results found is shown in Table 1.

Table 1. Relationship between concentration of boron and cadmium (ppm) and their intensities

\begin{tabular}{|c|c|c|}
\hline Boron and Cadmium Concentration (ppm) & Boron Intensity & Cadmium Intensity \\
\hline 0.0 & 0.100 & 0.400 \\
1.0 & 0.135 & 0.514 \\
2.0 & 0.160 & 0.551 \\
4.0 & 0.207 & 0.587 \\
6.0 & 0.248 & 0.696 \\
8.0 & 0.272 & 0.759 \\
10.0 & 0.292 & 0.800 \\
\hline
\end{tabular}

The relationship between $B$ and $C d$ concentration in a series of standards were shown in Figure 4 . The linear relationships were depicted, however, second order or quadratic relationships were not depicted but calculated. It was found that linear or first-order calibration curve for boron was $Y=0.0192 X+0.1172$ and its 
correlation coefficient value $r$ was 0.9837 , meanwhile, the quadratic or second-order calibration curve for boron was $Y=-0.0013 X^{2}+0.0138 X+0.1018$. In addition, it was found that first-order calibration curve of cadmium was $Y=0.0375 X+0.4493$ and correlation coefficient value $r$ was 0.9786 and its second-order calibration curve for cadmium was $Y=-0.0017 X^{2}+0.0545 X+0.4286$ where $Y$ is the intensity and $X$ is the concentration respectively. From the figure, it is obvious that calibration curve of cadmium starts highly deviating from zero, it is contrast to calibration curve of boron. In addition, based on first-order calibration curve for boron and cadmium found, the sensitivities of both elements are rather low.

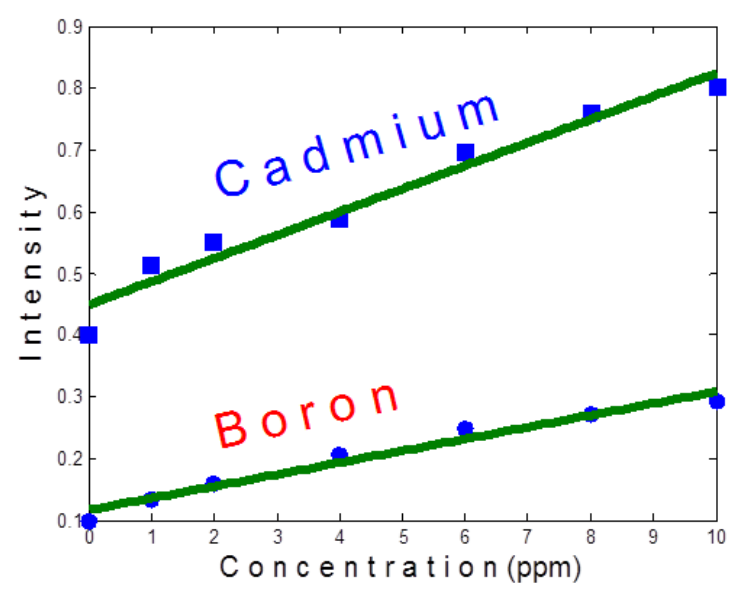

Figure 4. Calibration curves of boron and cadmium

Curvature or other systematic trends response can be attributed to chemical and physical source and also instrumental source. This can bring about large error in analysis if concentration of impurities $\mathrm{B}$ and $\mathrm{Cd}$ closed to background or limit of detection. Depression of B and $\mathrm{Cd}$ emission intensities are caused by reduction in both excitation temperature and electron number densities. To increase emission intensity, extremely high power is necessary to match excitation condition with larger electrodes used and without carrier distillation sample or standard in this experiment. It enables the complete atomization and excitation of the samples and standards during the excitation. Extremely high power can give rise quite violent, therefore special care had to be taken to have a save experiment and instrument. In addition, long life of emission spectrograph instrument have to be considered in highly priority scale, therefore to increase extremely high power in order to have ideal condition should be delayed.

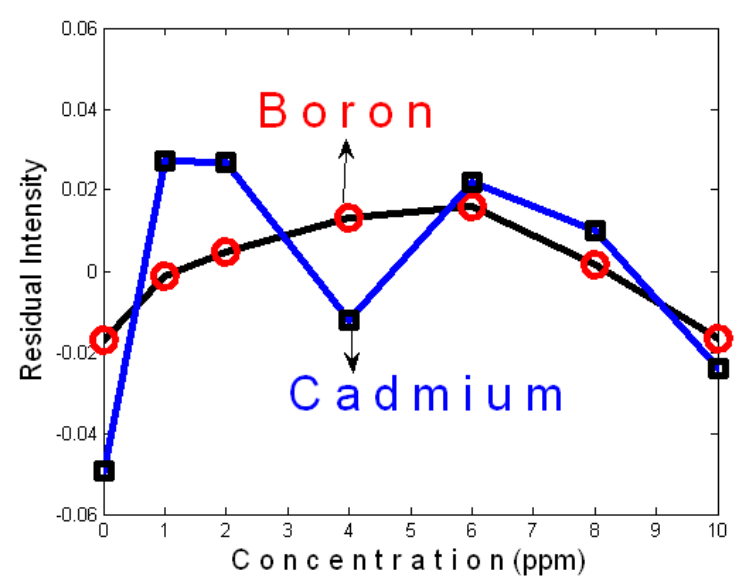

Figure 5. Residual of boron and cadmium

One of the drawback of this experiment has not always been stable of the beginning of $D C$ arc ignition, it needs 10 seconds for stability of the plasma. Therefore intensities of boron and cadmium are not as high as expected, because intensities of $B$ and $C d$ were caused by complex reaction in electrodes were just 15 seconds. 
The emission spectrograph instrument constant plays a vital role in the quantitative method. Ideally, it produces constant for all experiments. However, in practice, it varies from one experiment to others experiments because uncertainties of fundamental parameter. A uniform, free atom distribution within working electrode does not exist at all times during atomization $\mathrm{B}$ and $\mathrm{Cd}$, and degree of nonunivformmity depends on element-dependent, affected by the chemical narure of the surface ${ }^{(11,12)}$. Therefore, stability of excitation is depicted from residual intensities of both elements are different, where cadmium more scatter than boron which could be seen in Figure 5.

\section{Detection Limit.}

In analytical chemistry concept of limit of detection is used to described the lowest determined concentration of an analyte experimentally and statistically. Generally, analysis of impurities highly neutron absorber elements such boron and cadmium in thorium oxide at very low concentration is not easy to do. Theoretically, background of experiments have to be measured for ideal samples at least 20 times $^{(10)}$, it is not practical because it needs so many standards. The limit of detection of this method is calculated as 3 times the standard deviation of 5 blank standards which containing none of boron and cadmium in thorium oxide, yielding a detection limit $0.16 \mathrm{ppm}$ and $0.54 \mathrm{ppm}$ respectively. It is due to limited of number of electrodes which must be prepared in a special way to have. These detection limit can be improved by increasing the voltage, current and time of exposure, however, the apparatus used to examine has already been old one.

\section{Precision and Accuracy}

In order to check the accuracy of this method, boron and cadmium concentration was determined for some synthetic standards as shown in Figure 5 . Some of them were very accurate, however, some of them were not accurate. Determination of boron in $\mathrm{ThO}_{2}$ is more precision than cadmium. In general, the precision and accuration of boron and cadmium measurement in thorium oxide is very good since the electrode and working electrode were homemade one and without carrier destillation which was very important in emission spectrograph method.

\section{CONCLUSION}

In this study, the first application of analysis $\mathrm{B}$ and $\mathrm{Cd}$ in $\mathrm{ThO}_{2}$ in larger working electrode and without carrier distillation has been demonstrated. Although the quantitative analysis was done by densitometer instrument, however qualitative analysis was done by image processing in Matlab software. In future, the work should be examined and focused on the applications Matlab software for quantitative analysis and for separation of two or more peaks overlapped, In addition, the advantage of selectivity offered by image process should be developed and exploited by examining digital filter because it is very attractive.

\section{ACKNOWLEGMENT}

I sincerely thank Miss Dian (Chemistry Student of Yogyakarta State University) for preparing standards. I also thank to Mr.Tony Rahardjo for preparing graphite electrodes.

\section{REFERENCE}

1. SOCOLOW, R.H and STEPHEN W.P., A Plan to Keep Carbon in Check, Scientific American, Vol.295, No.3, Sep 2006.

2. KAZIMI,M.S."Thorium Fuel for Nuclear Energy", Scientific American, Vol. 91, No. 5 (2003) Sept 2003.

3. PERMANA, S TAKAKI, N and SEKIMOTO, H., "Feasible Region of Design Parameters for Water Cooled Thorium Breeder Reactor" Journal of Nuclear Science and Technology, Vol. 44, No. 7, 2007, p. 946-957.

4. HAROLD E (1958), Nuclear Engineering Handbook, Mc Graw Hill, USA

5. LARSON,G,F et al.,"Determination of Impurities in Uranium by ICP-AES after Separation with TBP", http://www.osti.gov/energycitation/product.biblo.jsp?osti_id=5833999, April 15, 2007 
6. SIMBOLON,S," An Improvement of Graphite Rod Electrode of Used Primary Cell for Analyzing Boron and Cadmium in Thorium Oxide Using Emission Spectrograph Method". J.Tek. Bah. Nuk, PTBN-BATAN, Vol. 5, No. 2, (2009), p. 71-82.

7. PRADYOT P, Handbook of Inorganic Chemicals (November 2001), McGraw-Hill, New York, Chicago, San Fransisco, Lisbon, London.

8. PURWANI, M.V, SUYANTI and DWI BIYANTORO., "Ekstraksi Th, La, Ce dan Nd dari Konsentrat ThLogam Tanah Jarang Hasil Olah Pasir Monazit Memakai TBP", Prosising Pertemuan dan Presentasi IImiah Penelitian Dasar IImu Pengetahuan Nuklir dan Teknologi Nuklir di PTAPB, Batan Yogyakarta July $12^{\text {nd }} 2005$.

9. SIMBOLON,S., Fuzzy Logic Application in Boron and Cadmium Analysis in $\mathrm{U}_{3} \mathrm{O}_{8}$ use of Emission Spectrograph Method., Atom Indonseia, Vol.37, No.1, April 2011 p.36-43

10. de LEVIE, R (2004)., How to Use Excel in Analytical Chemistry and General Scientfic Data Analysis. ISBN 0-511-04037-7 eBook. The Edinburgh Building, Cambridge CB2 2RU,UK.

11. Optical Emission Spectroscopy (Characterizing Plasma) www.nip.upd.edu.ph/plasma/ SPECWRKSHP.pdf, File Format: PDF/Adobe Acrobat - Quick View_ Optical Emission Spectroscopy. (Characterizing Plasma). February 21, 2007. Plasma Physics Laboratory. WORKSHOP...(January $30^{\text {th }}$ 2012)

12. CHAKRABARTI,C,L et al," Computer Modelling of Atomization Process in Graphite Furnance Atomic Absorption Spectrometry" Spectrochimica.Acta, Vol. 38B, No. 10, (1983), p. 1287-1300. 